\title{
Relationship among expression, amplification, and methylation of FE4 esterase genes in Italian populations of Myzus persicae (Sulzer) (Homoptera: Aphididae)
}

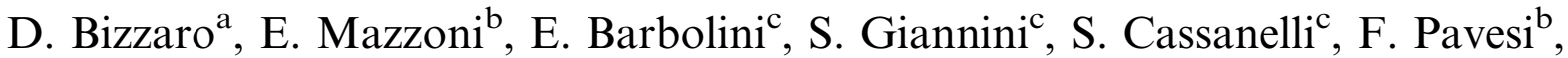 \\ P. Cravedi ${ }^{\text {b }}$, G.C. Manicardi ${ }^{\mathrm{c}, *}$ \\ a Istituto di Biologia e Genetica, Università Politecnica delle Marche, Ancona, Italy \\ ${ }^{\mathrm{b}}$ Istituto di Entomologia e Patologia Vegetale, Università Cattolica del Sacro Cuore, Piacenza, Italy \\ ${ }^{\mathrm{c}}$ Dipartimento di Scienze Agrarie, Università di Modena e Reggio Emilia, Reggio Emilia, Italy
}

Received 8 June 2004; accepted 22 September 2004

\begin{abstract}
The wide use of insecticides containing an esteric group selected resistant Myzus persicae populations characterised by the overproduction of one of two closely related carboxylesterases (E4 and FE4). In this paper, we present data collected from Italian population indicating that all the 22 populations analysed possess amplified FE4 gene only. The estimation of FE4 copy number, carried out by densitometric scanning of dot and Southern blots, puts in evidence that the different populations possess a gene copy number ranging from 6 to 104. Statistical analysis shows the existence of a high positive correlation between gene copy number and total esterase activity. In aphid strain with low FE4 copy number, these genes are almost totally methylated. On the contrary, aphid strains with high FE4 gene number evidenced highly variable methylation levels and absence of correlation between the number of genes and their methylation state. The same result has been observed when comparing FE4 methylation levels and esterase activity.
\end{abstract}

(c) 2004 Elsevier Inc. All rights reserved.

Keywords: Insecticide resistance; Gene amplification; Esterase; Methylation; Myzus persicae

\footnotetext{
* Corresponding author. Fax: +39 522522053.

E-mail address: manicardi.giancarlo@unimore.it (G.C. Manicardi).
}

\section{Introduction}

Aphids represent a taxon of sap-sucking insects very interesting for the agricultural entomology, not only for their direct damage, but also because they represent active virus vectors of several crops. The peach potato aphid Myzus persicae (Sulzer) 
represents a serious pest on a wide range of agricultural and horticultural crops in the whole Europe included Italy, in which the most damaged cultivation are peach orchards and field cultures as sugar beet, potato, and tobacco [1].

To preserve the economic value of production, the use of insecticide treatments against this pest is an unavoidable step in many crops cultivation. Unfortunately, the extended use of insecticides has selected $M$. persicae populations resistant towards the chemical products employed [2].

In Europe, the first cases of insecticide resistance in $M$. persicae were described in the $60^{\prime}$ both in glasshouses and in herbaceous crops [3-5].

Now, at least four resistance mechanisms have been discovered in $M$. persicae [6,7] and 3 out 4 are "target site insensitivity," but the first resistance mechanism discovered was of the "metabolic type" and acts against organophosphate, pyrethroid, and carbamate insecticides [3]. The involved enzymes are carboxylesterases that are able, at various degree, to sequester and hydrolyse the insecticide molecules with an esteric group before they can reach their target sites [8]. These enzymes are overproduced by the amplification of genes that code for two very similar forms of carboxylesterases: E4 and FE4 [9,10]. These two genes present a sequence homology of $99 \%$ and, whereas, the E4 genes are generally amplified in a single cluster (more rarely three clusters), the FE4 genes are distributed alongside $M$. persicae genome as multiple clusters (from three to eight sites) [11]. The E4 amplified form is highly widespread especially in the north of Europe and is correlated with a particular translocation between autosomes 1 and 3 [12], whereas, the FE4 form (which is not associated with chromosomal rearrangements) is typical of the Mediterranean regions, even if recent data attests a shift from E4 to FE4 form in English populations [13].

Depending on the esterase activity, Devonshire et al. $[14,15]$ classified resistant $M$. persicae populations into four classes: $\mathrm{S}$ (susceptible), R1 (moderately resistant), R2 (very resistant), and R3 (extremely resistant). Biochemical assays have shown that a significant proportion of Italian populations of $M$. persicae collected mainly from the primary host have a total esterase activity like R2 and, in a less extent, R3 population $[16,17]$.

Molecular analyses have demonstrated that both E4 and FE4 genes possess methylated $\mathrm{CpG}$ sites in the coding region or in the nearest genomic areas $[18,19]$. In $M$. persicae populations with the amplification of E4 genes, the disappearance of resistance is associated with the loss of methylation in these genes, that is the opposite situation generally found in vertebrates, where methylation correlates with genes silencing $[18,19]$.

The poor knowledge of the molecular basis that causes the appearance of mechanisms of insecticide resistance in pest crops can hamper the development of programs aimed to control their diffusion. To fill this gap and to complete the biological and biochemical data previously reported [17], we have performed a study on Italian population of $M$. persicae aimed to: (i) identify the gene responsible for esterase based insecticide resistance; (ii) estimate the gene amplification levels in each population in respect of esterase activity; and (iii) analyse the relationships among methylation levels, amplification, and expression of genes responsible for esterase based insecticide resistance.

\section{Materials and methods}

\subsection{Insects}

Myzus persicae populations used in this study have been collected in Italian peach orchards, or on herbaceous plants very near peach trees during the migration to the secondary host (Table 1). In addition, two strains were used as references: US1L, a fully susceptible strain kindly provided by Devonshire, Rothamsted Research and $800 \mathrm{~F}$, a strain originated from an Italian peach orchard with a known FE gene copy number [11]. Each population had been established as a clone from a single aphid collected from the field and maintained as a colony of parthenogenetic females on pea seedlings (cv "Meraviglia d'Italia") at $21^{\circ} \mathrm{C}$ and $16: 8$ light:dark photoperiod. 
Table 1

Myzus persicae populations used in this study

\begin{tabular}{|c|c|c|c|c|c|}
\hline No. & Collection place & & Gene copies (No.) & Methylation $(\%)$ & Absorbance $(620 \mathrm{~nm})($ mean $\pm \mathrm{SE})$ \\
\hline & Northern Italy & & & & \\
\hline 3 & ER_Bologna & IPM/conventional & $98(90-106)$ & $48(44-52)$ & $1.508 \pm 0.174$ \\
\hline 4 & ER-Ravenna & Experimental field & $94(90-98)$ & $39(35-43)$ & $1.241 \pm 0.117$ \\
\hline 6 & ER-Pontenure & Garden & $86(84-88)$ & $52(40-64)$ & $1.437 \pm 0.096$ \\
\hline 7 & ER_Argenta & IPM/conventional & $74(72-76)$ & $87(79-95)$ & $0.926 \pm 0.035$ \\
\hline 8 & ER-Ravenna & IPM/conventional & $66(66-66)$ & $68(59-77)$ & $1.362 \pm 0.093$ \\
\hline 9 & PM-Torino & Organic & $54(52-56)$ & $52(43-61)$ & $0.844 \pm 0.043$ \\
\hline 10 & ER-San Nicol & Experimental field & $66(60-72)$ & $65(60-70)$ & $0.814 \pm 0.074$ \\
\hline 11 & ER-Ferrara & IPM/conventional & $74(74-74)$ & $57(55-59)$ & $0.971 \pm 0.069$ \\
\hline 12 & ER_Argenta & IPM/conventional & $86(82-90)$ & $20(17-23)$ & $1.150 \pm 0.091$ \\
\hline 15 & ER-Ravenna & IPM/conventional & $94(84-104)$ & $52(49-55)$ & $1.461 \pm 0.045$ \\
\hline 16 & ER-Rivergaro & Garden & $102(96-108)$ & $60(51-69)$ & $1.147 \pm 0.041$ \\
\hline 17 & ER_Piacenza & Garden & $66(62-70)$ & $12(10-14)$ & $0.817 \pm 0.038$ \\
\hline 18 & ER_-Brisighella & IPM/conventional & $90(86-94)$ & $70(65-75)$ & $1.510 \pm 0.046$ \\
\hline 19 & ER_Piacenza & Garden & $10(10-10)$ & $100(100-100)$ & $0.353 \pm 0.036$ \\
\hline 20 & ER_-Brisighella & IPM/conventional & $82(78-86)$ & $63(55-71)$ & $1.085 \pm 0.054$ \\
\hline 24 & ER_-Imola & Organic & $90(88-92)$ & $10(8-12)$ & $1.099 \pm 0.071$ \\
\hline 31 & ER_Piacenza & Garden & $6(6-6)$ & $95(95-95)$ & $0.307 \pm 0.016$ \\
\hline \multirow[t]{2}{*}{32} & ER-Piacenza & Garden & $6(6-6)$ & $95(92-98)$ & $0.278 \pm 0.017$ \\
\hline & Central Italy & & & & \\
\hline 1 & TS_-Pisa & IPM/conventional & $26(24-28)$ & $100(100-100)$ & $0.252 \pm 0.020$ \\
\hline \multirow[t]{2}{*}{26} & TS_-Pisa & IPM/conventional & $10(10-10)$ & $95(90-100)$ & $0.289 \pm 0.019$ \\
\hline & Southern Italy & & & & \\
\hline 22 & $\mathrm{CB}$-Castrovillari & IPM/conventional & $106(102-110)$ & $74(69-79)$ & $1.189 \pm 0.050$ \\
\hline \multirow[t]{2}{*}{23} & CB-Lamezia T. & Garden & $10(10-10)$ & $100(100-100)$ & $0.255 \pm 0.038$ \\
\hline & Reference strains & & & & \\
\hline $\mathrm{U}$ & Susceptible US1L & & $4(4-4)$ & $0(0-0)$ & $0.168 \pm 0.009$ \\
\hline $\mathrm{F}$ & $800 \mathrm{~F}$ & & $80(76-84)$ & $95(92-98)$ & $1.620 \pm 0.089$ \\
\hline
\end{tabular}

Region of origin: ER, Emilia Romagna; PM, Piedmont; TS, Tuscany; and CB, Calabria.

\subsection{Biochemical assays}

Biochemical assays to assess total esterases in homogenates of individual aphids (30 specimens for each clone) were performed as described before [17].

Briefly, single aphids were homogenised in phosphate buffer $(20 \mathrm{mM}, \mathrm{pH} 7$, with $0.1 \%(\mathrm{v} / \mathrm{v})$ Triton X-100). One quarter $(25 \mu \mathrm{l})$ of each homogenate was transferred in a well of a microtiterplate, and after adding $25 \mu \mathrm{l}$ of buffer it was incubated, at room temperature, with $\alpha$-napthylacetate $(300 \mu \mathrm{M}, 150 \mu \mathrm{l})$. After $5 \mathrm{~min}, 25 \mu \mathrm{l}$ of diazo-blue/lauryl sulphate reagent (DBLS) was added and after $20 \mathrm{~min}$ absorbance at $620 \mathrm{~nm}$ was mea- sured with a Titertek Multiskan Plus MKII microplate reader.

\subsection{Extraction, digestion, and electrophoretic analysis of $D N A$}

Genomic DNA was isolated and purified from several parthenogenetic adult females as previously described [20], quantified by spectrophotometric absorbance measurements at $260 \mathrm{~nm}$ and subjected to agarose gel electrophoresis to confirm the high molecular DNA quality. Total DNA $(10 \mu \mathrm{g})$ was digested with $20 \mathrm{U}$ of MspI, HpaII or EcoRI in the appropriate buffer (Roche) at $37^{\circ} \mathrm{C}$ overnight and electrophoresed in $1.2 \%$ 
agarose gels in Tris-borate-EDTA buffer, $\mathrm{pH}$ 8, at $50 \mathrm{~V}$. Molecular weights were evaluated by using DIG labelled Molecular Weight Marker III (Roche).

\subsection{Southern and dot blots}

The transfer of DNA from agarose gel to nylon membrane (Hybond-N+, Amersham) was performed by treating agarose gels first in $250 \mathrm{mM}$ $\mathrm{HCl}$ for $5 \mathrm{~min}$ at room temperature, then in denaturation solution $(0.5 \mathrm{~N} \mathrm{NaOH}, 1.5 \mathrm{~N} \mathrm{NaCl})$ for $30 \mathrm{~min}$, and finally in neutralisation buffer $(1.5 \mathrm{~N}$ $\mathrm{NaCl}, 0.5 \mathrm{M}$ Tris- $\mathrm{HCl}, \mathrm{pH} 7.5$ ) twice for $15 \mathrm{~min}$. DNA was then blotted overnight by capillary transfer onto the membrane using 10× SSC (salt sodium citrate) buffer and fixed by UV-crosslinking. The membrane was utilised immediately for pre-hybridisation in a rolling-bag containing $10 \mathrm{ml}$ of DIG Easy Hyb solution (Roche) at $45^{\circ} \mathrm{C}$ for $1 \mathrm{~h}$. Hybridisation was performed in a rolling-bag containing $10 \mathrm{ml}$ of hybridisation solution (DIG Easy $\mathrm{Hyb}$ ) added with $40 \mathrm{ng} / \mathrm{ml}$ probe at $50{ }^{\circ} \mathrm{C}$ for $16 \mathrm{~h}$. The probe was denatured by boiling for $6 \mathrm{~min}$. At the end of hybridisation the membrane was washed twice in $2 \times \mathrm{SSC}$ for $15 \mathrm{~min}$ at room temperature, then in $0.1 \times \mathrm{SSC}$ for $15-30 \mathrm{~min}$ at $68^{\circ} \mathrm{C}$ and treated for the detection of hybridisation signals according to Roche DIG-chemioluminescent protocols.

Dot blots were set up by hand, spotting serially diluted aliquots of each DNA sample on a nylon membrane. Prior to spotting, each DNA sample was added with non-homologous salmon sperm DNA in $0.4 \mathrm{~N} \mathrm{NaOH}, 10 \mathrm{mM}$ EDTA, and denatured by boiling and cooling on ice. Membrane hybridisation and detection were performed as described for Southern blot hybridisation. The Digoxigenin-labelled DNA probe used for all filter hybridisations consist in a linearised plasmid DNA containing a $8 \mathrm{~kb}$ genomic DNA fragment corresponding to $4 \mathrm{~kb}$ of $\mathrm{E} 4$ gene sequence and $4 \mathrm{~kb}$ $5^{\prime}$ downstream flanking DNA kindly furnished by Field and Devonshire (Rothamsted Research, UK).

FE4 plus E4 diploid gene copy number in each Italian populations of $M$. persicae were evaluated by quantitative estimation of hybridisation signal intensity on dot blots and EcoRI Southern blots, considering equal to 4 the E4 plus FE4 gene copy number in the reference fully susceptible clone No. 33 (US1L) and 80 the FE4 plus E4 gene copy number in the $800 \mathrm{~F}$ strain [11].

The methylation level analyses of amplified FE4 genes were performed on Southern blot with E4 probe of MspI and HpaII digested DNA. The completion of DNA digestions were verified by time course digestion assays. For each population, the relative intensity of the two diagnostic bands [21] at 2.8 and $1.8 \mathrm{~kb}$ in $M s p \mathrm{I}$ and $H p a I I$ lane, was compared, and the methylation levels of FE4 genes on M2 and M3 restriction sites, evaluated.

Densitometric analysis and quantification was done using the freeware program Scion Image for Windows, available from www.scioncorp.com.

\section{Results}

Most of the analysed populations showed a total esterase activity comparable with that of resistant strains (R2, R3), whereas, only few populations had a esterase activity as susceptible strains (S) (Table 1).

RFLP experiments utilising both $M s p \mathrm{I}$ and EcoRI restriction endonucleases, which allow a clearcut distinction between E4 and FE4 genes [21], demonstrated that all the 22 Italian populations analysed showed the FE4 diagnostic band of $1.8 \mathrm{~kb}$ after MspI digestion (Fig. 1A) and of $4 \mathrm{~kb}$ after EcoRI digestion (Fig. 1B). The estimation of FE4 copy number, carried out by densitometric scanning of dot and Southern blots performed utilising an E4 cDNA as a probe, puts in evidence that the different populations possess a gene copy number ranging from 6 to 104 (see Table 1). Statistical analysis showed the existence of a high positive correlation between gene copy number and total esterase activity attesting resistance levels $\left(r^{2}=0.85 ; P<0,01 ; n=22\right)$ (Fig. 2).

The estimation of the methylation pattern in M2 and M3 restriction sites on FE4 gene carried out comparing MspI and HpaII RFLP patterns (Fig. 3) showed variable methylation levels in the different populations (Table 1). 


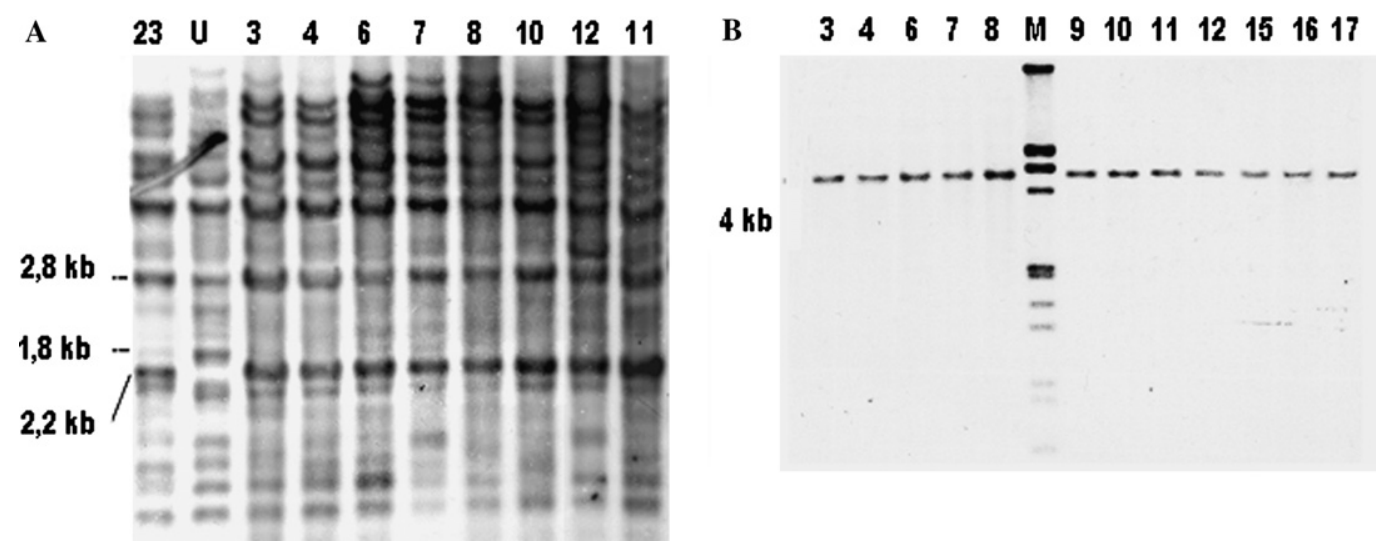

Fig. 1. Southern blot of $M s p I$ (A) and EcoRI (B) digested DNA, in some Italian populations of M. persicae. A fully susceptible English population (US1L named U in the A) used as reference is easily distinguishable by the presence of the E4 diagnostic band at $2.2 \mathrm{~kb}$, and the absence of the FE4 diagnostic band at $1.8 \mathrm{~kb}$ which is present in all Italian strains. In (B), note the presence of the FE4 diagnostic band at $4 \mathrm{~kb}$ in all strains digested with EcoRI. M represents DIG labelled Molecular Weight Marker III (Roche).

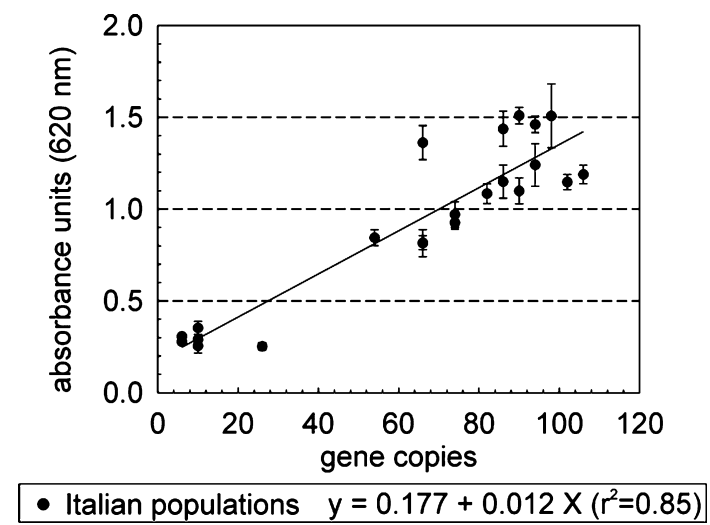

Fig. 2. Correlation between FE4 gene copy number and total esterase activity, reported as absorbance units $( \pm \mathrm{SE})$ measured at $620 \mathrm{~nm}$ in each strain of $M$. persicae analysed.

In aphid strain with low FE4 copy number (624), these genes were almost totally methylated. On the contrary, aphid strains with high FE4 gene number (more than 24) evidenced highly variable methylation levels even in presence of equal FE4 copy number (Fig. 4) and a complete absence of relationship between FE gene copy number and methylation state $\left(r^{2}=0.002 ; P=0.86 ; n=16\right)$.

The same result was observed when comparing esterase activity and FE4 methylation levels. In fact, $M$. persicae strains with higher esterase activity (high level of gene expression and esterase based insecticide resistance), showed levels of esterase activity varying independently from the FE4 gene methylation levels $\left(r^{2}=0.023\right.$; $P=0.57 ; n=16$ ) (Fig. 5).

\section{Discussion}

The results presented in this paper constitute the first overview regarding the molecular basis of esterase insecticide resistance in Italian populations of M. persicae. Previous data based on biochemical assays have demonstrated that, in Italy, esterase based insecticide resistance represents a serious problem for pest management since most of the analysed populations showed a total esterase activity comparable with resistant strains (R2) or highly resistant strains (R3) [17]. Molecular analysis put in evidence that all populations examined possess a wide range of copy numbers of FE4 gene only, whereas, differently to what observed in UK [13], gene amplification do not involve E4 form. Moreover, it must be underlined that in English populations it is relatively unusual to find the R3 enzyme levels associated with FE4 [13].

As already evidenced for English strains with amplification of E4 genes [11], statistical analysis carried out on Italian strains shows the existence 


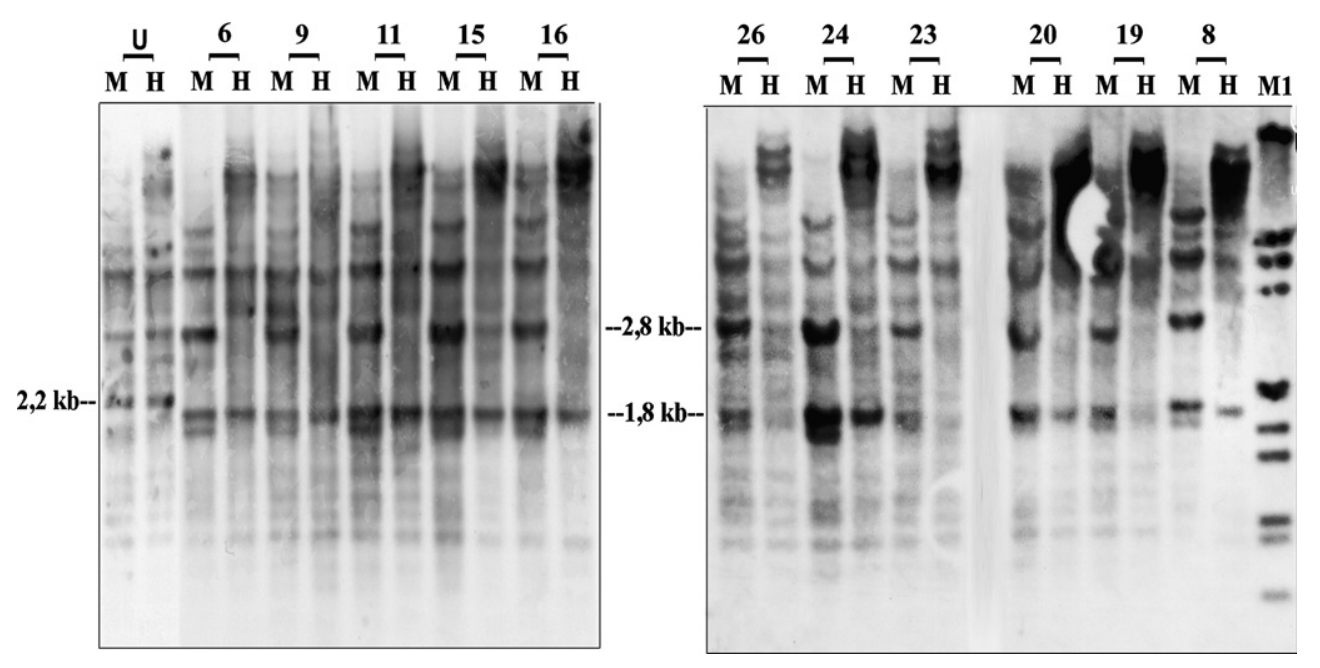

Fig. 3. Southern blot with E4 probe of $M s p \mathrm{I}(\mathrm{M})$ and HpaII (H) digested DNA, in some Italian populations of M. persicae. U strain (US1L) comes from an English susceptible population: note the presence of the E4 diagnostic band at $2.2 \mathrm{~kb}$. For each population, the relative intensity of the two bands at 2.8 and $1.8 \mathrm{~kb}$ in $\mathrm{H}$ and $\mathrm{M}$ lane, was compared, and the percentage of unmethylated FE4 genes evaluated. M1 represents DIG labelled Molecular Weight Marker III (Roche).

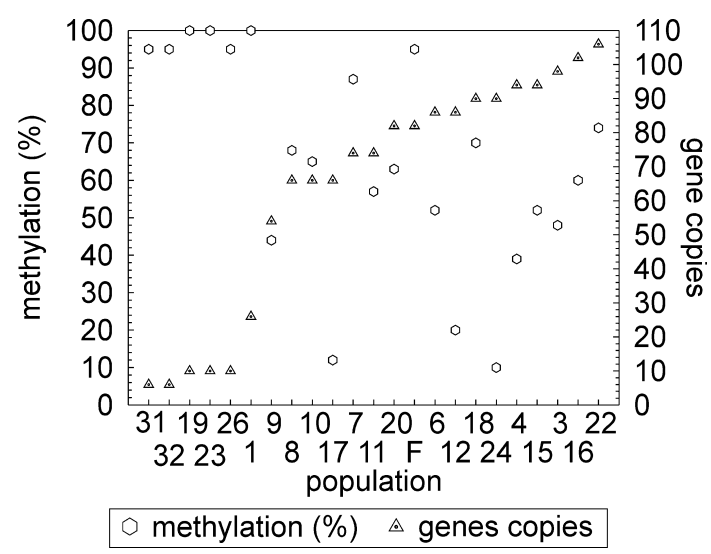

Fig. 4. Comparison between the methylation levels and total number of FE4 genes in all the Italian strains analysed. Note that in aphid strain with low FE4 copy number, these genes are almost totally methylated. On the contrary, aphid strains with high FE4 gene number evidenced highly variable methylation levels.

of a significant relationship between FE4 gene copy number and esterase activity thus indicating that gene amplification and not overexpression is the main cause of carboxylesterase overproduction in $M$. persicae. The maximum copy number found in an Italian population, reaching approx. 100, re-

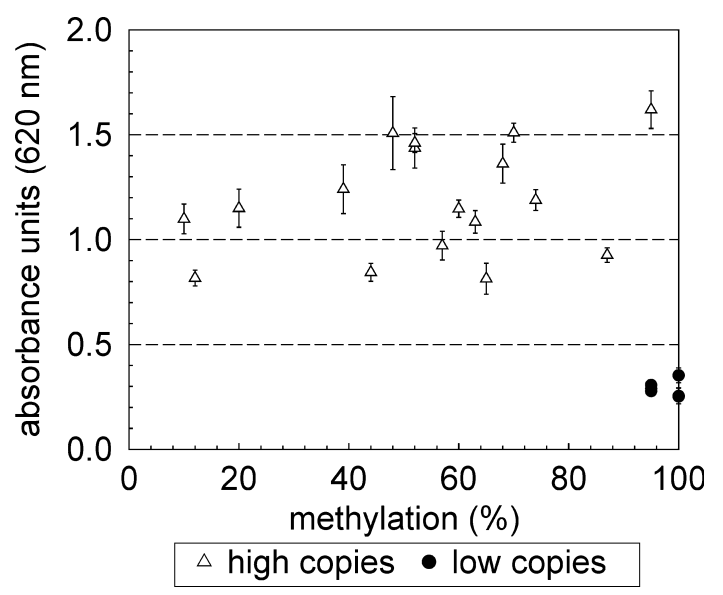

Fig. 5. Comparison between the methylation levels of FE4 genes and absorbance values attesting total esterase activity in all Italian populations. Note that aphid strains with high FE4 gene number evidenced highly variable methylation states even in presence of similar absorbance values.

sults slightly higher that the one found for both E4 and FE4 in UK populations [11].

Overproduction of the esterases E4 and FE4 in $M$. persicae depends on both gene amplification and transcriptional control, the latter being associated with changes in DNA methylation 
$[11,18,19,22]$. In fact both E4 and FE4 genes possess methylated $\mathrm{CpG}$ sites in the coding region or in nearest genomic areas [19]. Contrary to what observed in vertebrates [23], in M. persicae strains characterised by E4 mediated resistance, all the amplified genes are methylated and the loss of insecticide resistance, resulting from decreased esterase activity, is associated to gene demethylation [19]. On the basis of such observations, it has been suggested that in $M$. persicae methylation has a positive role in expression of the genes coding for carboxylesterase E4 [19]. The data presented in this paper indicate that in Italian $M$. persicae strains possessing high copy number of FE4 genes, esterase gene expression resulted unrelated with the degree of methylation. The same result was observed when methylation levels and the number of FE4 copies were compared. In particular, whereas in aphid strains with low FE4 copy number, these genes were almost totally methylated, aphid strains with high FE4 gene number evidenced very different methylation states also in presence of equal number of gene copies (Fig. 5). A possible explanation for this discrepancy between English and Italian populations could be linked to the different distribution of E4 and FE4 amplicons in $M$. persicae genome. In fact, whereas amplified E4 sequences are almost always located at a single chromosomal site, amplified FE4 genes occur on several chromosomes as clearly demonstrated in peach-growing populations from Greece [24]. The widespread distribution of FE4 amplicons could reduce the epigenetic control of amplicon expression through DNA methylation. On the other hand, the fact that in M. persicae clones with low FE4 copy number, these genes were almost totally methylated suggests that FE4 genes needs at least a certain amount of 5-methyl-cytosine to be expressed.

\section{Acknowledgments}

The authors thank Linda M. Field and Alan L. Devonshire, Rothamsted Experimental Station, $\mathrm{UK}$, for providing a clone of the E4 gene and the E4 susceptible strain of $M$. persicae. This work was supported by a grant from the Ministero della
Ricerca Scientifica e Tecnologica (MURST) of Italy.

\section{References}

[1] P. Cravedi, E. Mazzoni, R. Serra, Bioassays of some insecticides on the green peach potato aphid Myzus persicae (Sulzer) in Northern Italy: a preliminary survey, Boll. Zool. Agric. Bachicol. Serie II 23 (1991) 113-121.

[2] A.L. Devonshire, L.M. Field, S.P. Foster, G.D. Moores, M.S. Williamson, R.L. Blackman, The evolution of insecticide resistance in the peach potato aphid, Myzus persicae, Phil. Trans. R. Soc. Lond. B 353 (1998) 1677-1684.

[3] P.H. Needham, R.M. Sawicki, Diagnosis of resistance to organophosphorus insecticides in Myzus persicae (Sulzer), Nature 230 (1971) 125-126.

[4] J. Hurkova, Multiple resistance to insecticides in greenhouse samples of Myzus persicae (Sulz.) (Homoptera, Aphidoidea), Acta Entomol. Bohemos. 70 (1973) 13-19.

[5] K.I. Sudderuddin, Studies of insecticide resistance in Myzus persicae (Sulz.) (Hem., Aphididae), Bull. Entomol. Res. 62 (1973) 533-539.

[6] M.F. Field, A.P. Anderson, I. Denholm, S.P. Foster, Z.K. Harling, N. Javed, D. Martinez-Torres, G.D. Moores, M.S. Williamson, A.L. Devonshire, Use of biochemical and DNA diagnostics for characterising multiple mechanisms of insecticide resistance in the peach-potato aphid, Myzus persicae (Sulzer), Pestic. Sci. 51 (1997) 283-289.

[7] N. Anthony, T. Unruh, D. Ganser, R. ffrench-Constant, Duplication of the Rdl GABA receptor subunit gene in an insecticide-resistant aphid, Myzus persicae, Mol. Gen. Genet. 260 (1998) 165-175.

[8] A.L. Devonshire, G.D. Moores, A carboxylesterase with broad substrate specificity causes organophosphorus, carbamate and pyrethroid resistance in peach-potato aphids (Myzus persicae), Pest. Biochem. Physiol. 18 (1982) 235246.

[9] A.L. Devonshire, G.D. Moores, C.L. Chiang, The biochemistry of insecticide resistance in the peach-potato aphid, Myzus persicae, in: Proc. 5th Internat. Cong. Pest. Chem., vol. 3, Pergamon Press, Oxford, 1983, pp. 191$196 .$.

[10] L.M. Field, A.L. Devonshire, B.G. Forde, Molecular evidence that insecticide resistance in peach-potato aphids (Myzus persicae Sulzer) results from amplification of an esterase gene, Biochem. J. 251 (1988) 309-312.

[11] L.M. Field, R.L. Blackman, C. Tyler-Smith, A.L. Devonshire, Relationship between amount of esterase and gene copy number in insecticide-resistant Myzus persicae (Sulzer), Biochem. J. 339 (1999) 737-742.

[12] R.L. Blackman, H. Takada, Y. Kawakami, Chromosomal rearrangement involved in insecticide resistance of Myzus persicae, Nature 271 (1978) 450-452.

[13] L.M. Field, S.P. Foster, Amplified esterase genes and their relationship with other insecticide resistance mechanisms in 
the English populations of the aphid, Myzus persicae (Sulzer), Pest. Manag. Sci. 58 (2002) 889-894.

[14] A.L. Devonshire, G.D. Moores, R.H. ffrench-Constant, Detection of insecticide resistance by immunological estimation of carboxylesterase activity in Myzus persicae (Sulzer) and cross-reaction of the antiserum with Phorodon humulii (Schrank) (Hemiptera. Aphididae), Bull. Entomol. Res. 76 (1986) 97-107.

[15] A.L. Devonshire, G.J. Devine, G.D. Moores, Comparison of microplate esterase assays and immunoassay for identifying insecticide resistant variants of Myzus persicae (Homoptera: Aphididae), Bull. Entomol. Res. 82 (1992) 459-463.

[16] E. Mazzoni, P. Cervato, P. Cravedi, Present status of insecticide resistance in Myzus persicae in northern Italy peach orchards, IOBC Bull. 22 (1999) 39-43.

[17] E. Mazzoni, P. Cravedi, Analysis of insecticide-resistant Myzus persicae (Sulzer) populations collected in Italian peach orchards, Pest. Manag. Sci. 58 (2002) 975-980.

[18] L.M. Field, A.L. Devonshire, R.H. ffrench-Costant, B.G. Forde, Changes in DNA methylation are associated with loss of insecticide resistance in the peach potato aphid Myzus persicae (Sulz), FEBS Lett. 243 (1989) 323-327.
[19] L.M. Field, Methylation and expression of amplified esterase genes in the aphid Myzus persicae (Sulzer), Biochem. J. 349 (2000) 863-868.

[20] D. Bizzaro, G.C. Manicardi, U. Bianchi, Chromosomal localization of a highly repeated EcoRI DNA fragment in Megoura viciae (Homoptera, Aphididae) by nick translation and FISH, Chromosome Res. 4 (1996) 392-396.

[21] R.L. Blackman, J.M. Spence, L.M. Field, N. Javed, G.J. Devine, A.L. Devonshire, Inheritance of the amplified esterase genes responsible for insecticide resistance in Myzus persicae (Homoptera: Aphididae), Heredity 77 (1996) 154-167.

[22] C.A. Hick, L.M. Field, A.L. Devonshire, Changes in the methylation of amplified esterase DNA during loss and reselection of insecticide resistance in the peach-potato aphid, Myzus persicae, Insect Biochem. Mol. Biol. 26 (1996) 41-47.

[23] A. Bird, DNA methylation patterns and epigenetic memory, Genes Dev. 16 (2002) 6-21.

[24] R.L. Blackman, J.M. Spence, L.M. Field, A.L. Devonshire, Variation of amplified esterase (FE4) genes in Greek field populations of Myzus persicae (Sulzer), Heredity 82 (1999) 180-186. 